\title{
Rahvaortodokslus, ametlik kirik ja riik Soome Raja-Karjalas enne II maailmasõda
}

$\underline{\text { Teuvo Laitila }}$

\section{Oma pärimuse kindlustamine: karjala rahvapärase ortodoksluse moodustumine u 1000 - 1600}

Karjala kultuuriks loetav kultuur sündis praeguse arusaama järgi Laadoga lääne- ja loodekaldal esimese kristliku aastatuhande lõpul. Selle õitseaeg sattus ligikaudu ristisõdade aega, umbes aastatesse 1100-1300. Kultuuri tuumpiirkonna kasutamise ja valdamise pärast pidid karjalased võitlema hämelaste ja hiljem rootslastega ning Novgorodi peaasjalikult slaavlastest elanikega. Kultuuri õitseaja ebakindlusest jutustavad muuhulgas paljud piirkonnast leitud linnamäed, mida kasutati elu-, pao- ja turvapaikadena (Huovila 1995: 10, 12-14, 19-20).

Karjala õitseaja suhteliselt kõrge kultuur viitab sellele, et kõnealune ühiskond oli sotsiaalselt struktuurilt üpris keerukas. Üldiselt on niisuguses ühiskonnas ka usundispetsialiste. Seega võiks oletada, et karjalastel oli oma, suhteliselt arenenud usundiline süsteem, mis osalt tugevdas ja säilitas nende sotsiaalseid struktuure.

Ristiusu levimine sellesse piirkonda meie ajaarvamise esimese aastatuhande lõpul tähendas väljakutset karjala kultuurile üleüldse ja usundile iseäranis. Kõige kindlamat varaseimat teavet kristluse saabumisest annavad haualeiud. Esimese ja teise aastatuhande vahetusest pärinevatest Karjala haudadest on leitud muuhulgas Bütsantsi rahasid ja riste. Need jõudsid kohale kas otseste kaubandussidemete kaudu või 10.-11. sajandi vahetusel ristiusu vastu võtnud Novgorodi vahendusel.

Kindel kirjalik viide ristiusu leviku kohta Karjalas leidub 13. sajandi algupoolelt. Vanima Vene kroonika, nn Nestori kroonika laiendatud versioon, Laurentiustekst, jutustab, et Novgorod ründas 1227. aastal hämelasi. Sellel retkel Novgorodi vürst Jaroslav «läkitas ristima suuremat osa karjalastest, peaaegu kõiki inimesi» (Kirkise soome tõlke järgi [1987]). Augustin (1991: 34) usub, et karjalaste «massilisele ristimisele 1227. a järgnes tõenäoliselt kirikute ja kloostrite ehitamine».

Selsamal ajal sattus Karjala Rooma kiriku õpetuse omaks võtnud Lääne-Euroopa ja Bütsantsi kristluse säilitanud Ida-Euroopa vahelisse võimuvõitlusse. Religioosselt ja majanduslikult kuulusid karjalased ida (Novgorodi) piirkonda, kuid poliitiliselt näib nende usaldatavus olevat 13 . sajandi teisel poolel sattunud kahtluse alla. Aastal 1278 juhtis Vladimiri - mis oli sel ajal Novgorodi vürstiriigi pealinn - vürst Dmitri, Aleksander Nevski poeg, sõjaväge, mis Novgorodi kroonika kohaselt «karistas Korela asukaid ja vallutas nende maa» (CN 1970: 107). Novgorodi ja Rootsi tüli karjalaste maa pärast lahendati vormiliselt 1323. aasta augustis Pähkinäsaare rahulepingu sõlmimisega. Sellega tunnustati karjalaste põhilise ala edelaosa, Lääne-Kannase ja praeguse Soome kõige kagupool-

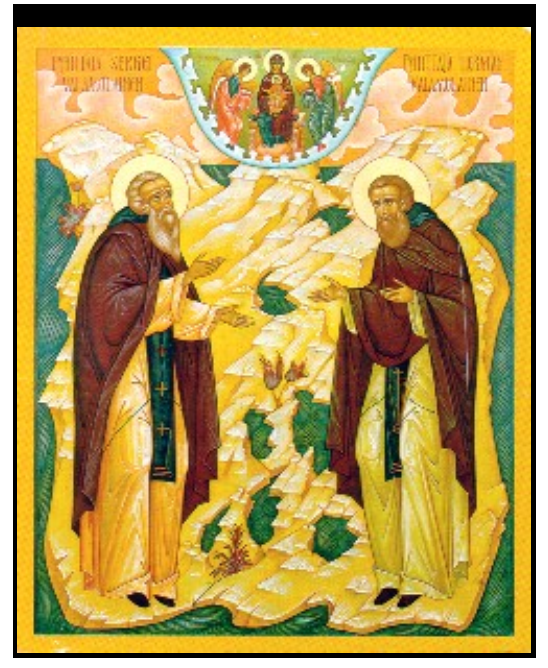
sema osa kuulumist Rootsi riigi alla. 
Laadoga lääneranna Karjala aladel sai ortodokslus või vähemalt ortodoksne kombestik kindla positsiooni 15. sajandil. Kristluse mõju süvenemisest selle aja Laadoga-Karjalas jutustavad muuhulgas kloostrite rajamise muistendid ja keelelised seigad. Valamo kloostri rajamise aja suhtes ei olda päris üksmeelsed (vt Ohhotina 1993; Kirkinen 1995), kuid usutav tundub olevat 14. sajand. Sellal, pärimuse kohaselt 1393. aastal, rajati ka Konevitsa klooster. Mõlemad mõjutasid Karjala vaimulikku elu kristluse suunas, nagu võib otsustada näiteks mitmete paikkondlike pühakute (kasvõi näiteks Süvari Aleksandri ja mitmete tema õpilaste) elulugude järgi (nende kohta vt Piiroinen 1991: 25-40).

Ortodoksluse kindlustumisele Laadoga-Karjalas 15. sajandi lõpul viitab ka see, et Novgorod ja viimase 1478. aastal oma võimu alla heitnud Moskva pöörasid oma tähelepanu 15. sajandi lõpul ja 16. sajandil rohkem põhja poole, Valge mere lõuna- ja läänerannikule. Solovetsi saartele Valges meres rajati erakla juba 15. sajandi algupoolel ja klooster veel samal sajandil.

Kristlikud isikunimed hakkasid eelkristlike kõrval esinema Laadoga-Karjalat puudutavates dokumentides 15. sajandil. Ilmselt samal ajal laenati karjala keelde slaavipärast kristlikku terminoloogiat, näiteks svjatoi (püha), pruasniekku (praasnik), pokoiniekku (surnu), Gospodi Suse (Issand Jeesus) ja Bogoroditshshu (Jumalasünnitaja) (Augustin 1991: 40). Vanematele, Novgorodi poolt juba 13. sajandil rajatud kirikuküladele ja maksukogumispiirkondadele, pogostatele lisaks oli Karjalasse 15. sajandil moodustatud vähemalt Ilomantsi, Kurkijoe, Käkisalmi, Salmi ja Sortavala pogostad. Ortodoksluse tugevnemisele 15. sajandil viitab ka nn Vadja maksustamispiirkonna ehk viiendiku (vene keeles Votskaja pjatina) 1500. aastal koostatud maksuloend. See on esimene teadaolev dokument, mis annab laiemat ajaloolist teavet Laadoga-Karjala ortodokslusest.

Maksuloendi järgi oli hiljem Käkisalmi lääniks nimetatud piirkond 1500. aastal jagatud seitsmeks pogostaks. Need olid Ilomantsi, Kurkijoki, Käkisalmi, Rautu, Sakkola, Salmi ja Sortavala, kuhu kuulus ka Suistamo (Kirkinen 1979: 99; Surakka 1936: 22-23). Nendes oli 13 suuremat ja umbes 40 väiksemat kirikut ja tsassounat ning 12 kloostrikirikut. Jumalateenistuspaikade olemasolu peaaegu igas vähegi suuremas külas osutab sellele, et kogu Vadja viiendik oli vähemalt vormiliselt liidetud ortodoksse kiriku püsiva toimimise alaga. Praktikas peeti väikestes pühakodades jumalateenistust ehk ainult üks kord aastas.

See ei tähenda siiski, et lihtrahvas oleks omaks võtnud ortodoksse usu, vähemalt täpselt kiri$\mathrm{ku}$ õpetatavas vormis. Teisalt on minu meelest eksitav kõnelda üksnes väliste kommete omandamisest (vrd nt Itkonen 1928), sest kommetega liitub alati mingi tõlgendus. Pigemini võiks väita, et 15. sajandil algas ortodoksluse kohandumine karjala eluviisiga, teisisõnu, hakkas kuju võtma Karjala rahvaortodokslus (vt Timonen 1990: 11).

Karjala pärimuse vabatahtlikule muutumisele või uuenemisele oli omane uue tõlgendamine vana taustraamis.

Kristlik Jumal, Jumalaema ja pühakud näiteks said mõistetavaks ja omaseks nende ühendamise kaudu eelkristliku uskumusmaailma samu ülesandeid täitnud «jumalatega». Nõnda näiteks sai prohvet Eelijast, karjalaste Iljast, muuhulgas äikesehaldjas, sest äikesel on tähele-

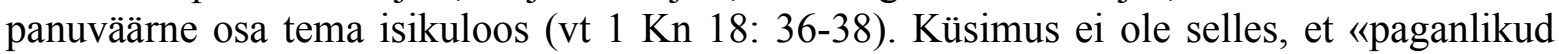
jumalad» või «haldjad» oleksid niimoodi endistena säilinud uute, kristlike nimede varju all (vrd Harva 1932; Itkonen 1928). Pigemini oli asi selles, et elavat eelkristlikku usundimaailma kujutati kristliku sõnakasutuse abil. Samal ajal elati seda läbi ja kogeti kristlikuna niimoodi nagu karjalased ise ristiusku mõistsid. Karjalane ütles näiteks Harva (1932: 472) järgi, et püha Miikkula (Nikolause) «andvat püünispaelast linnu» ja palus sellepärast Miikkulat enne linnupüüdmist. Eelkristlikku pärimust - antud juhul seotud üldnimega «jahihald- 
jas» - ja kristlikku traditsiooni - sama eluvaldkonnaga seotud pühakut - ei nähtud teineteise vastandeina, nagu see sündis tihtipeale kiriku ametlikus õpetuses, vaid erinevate viisidena kõnelda, antud juhul inimese ja looduse suhtest (vrd Eliade 1980: 7-8). Usundiloolane Mircea Eliade on nimetanud sellelaadilist mõtlemist «kosmiliseks kristluseks» (ibid.: 25).1

Kiriku juhtkond Novgorodis suhtus karjalapärasesse kristluse vastuvõtmisse kahel moel. Teoorias mõisteti rahvaortodokslus hukka kui «poolpaganlus», kuid praktikas seda sageli salliti. Sallimiseks oli kaks peamist põhjust. Piiriala kiriklik elu oli nõrgalt organiseeritud; vaimulikkond ei olnud arvukas ja selle tegevus oli väljaspool kiriklikke keskusi vähene. Teiseks oli piiriala poliitiliselt ebakindel ja rahvastikku ei tahetud ärritada liigse survamisega pöörduma Novgorodi - või hiljem Moskva - vastu.

Aeg-ajalt astus kirik paganluse kaotamiseks aktiivsemalt tege-vusse. 1526. aastal Novgorodi peapiiskopiks valitud Makari alustas oma ametiajal laiaulatuslikku misjonitööd Novgorodimaa põhjaosas, eriti Valge mere rannikul ja Koola poolsaarel asuvate rahvaste seas (Makari 1989: 55). Ühe osana sellest tööst läkitas ta 1534. aastal munkpreester Ilja Vadja viiendikku, Põhja-Aunusesse, Valge mere läänerannikule ja päris Petsamoni välja, et tuua tagasi kiriku rüppe neid, kes olid «ära eksinud tõelisest kristlikust usust» (viidatud: Kirkinen 1987: 126). Iljal oli kaasas karjasekiri, milles peapiiskop heitis rahvale ette, et see ristiusu vastuvõtmisest hoolimata säilitas esivanemate vanad tavad ehk «harrastas ebajumalateenistust», kummardas metsasalusid [tegu võis olla ohvrihiite ja/või sugukonnakalmistutega], kive, jõgesid, allikaid, mägesid, järvi, päikest, kuud ja tähti ning ohverdas neile härgi, lambaid ja muid loomi (Kirkinen 1987: 126, 128; Mikkola 1932: 243-244).

Makari süüdistas rahvast ka selles, et see sõi paastu ajal «ebapuhtaid» toite, mattis oma surnuid «paganlikesse» kalmistutesse ja haiguste korral otsis abi loitsudest ning pidas oma «preestriteks» nn arbujaid [teadjaid], kes juhtisid ohvri- ja matusetalitusi ning andsid lastele nimed (Kirkinen 1987: 128; Mansikka 1967: 226-229). Kiriku arusaama kohaselt oli teadjate juhitud riitustes osalemine peaaegu suurim patt, sest neis oli tegu saatana, mitte Jumala teenimisega.

Eelkristliku usundi mõju kristlusele ei paista olevat piirdunud karjalaste ja saamide aladega. Moskvas 155. a peetud nn sajandi kirikukogu (vene k stoglavny sobor) otsuste mõned kohad viitavad sellele, et ebausku ja paganlust esines ka Venemaa kesksetel aladel. Kirikukogu pani nimelt oma otsustes vande alla need, kes tantsivad surnuaial kolmainupüha laupäeval (nelipühadele eelnev nn hingede laupäev, surnute mälestamispäev) või karglevad ja vallatlevad jaaniööl, jõuluõhtul või kolmekuningapäeval. Vlassov (1990-91: 26) arvabki, et alles neil aegadel, 16.-17. sajandil, hakati Venemaa külakohtades omaks võtma ristiusku - kristlikke rituaale ja kristlikku kalendrit.

Pärast Makarit korraldas ta järeltulija, peapiiskop Feodossi II (ametis 1542-1551) 1548. aastal veel ühe misjoniretke Vadja viiendikku. Tema saadikuks oli Novgorodi preester Nikifor. Augustini (1991: 49) järgi oli Ilja ja Nikifori tegevusel tulemusi: 16. sajandi teisel poolel «saavutas kirik võidu paganluse üle». Väitele näib tuge andvat seik, et kesk- ja uue aja vahetusel kanoniseeris Venemaa kirik paikkondlikult üle 40 Karjala² pühaku, kellest 15 (muuhulgas Süvari Aleksander ja Siijoki Antoni) on võetud Vene kiriku üleriigilisse pühakute loetelusse (Ambrosius 1981: 320-323; Vlassov 1990-91: 29-30.)

Paljud Karjala pühakud olid küll vähemalt alguses pühad pigem rahvausundi kui ametliku kiriku nägemuse kohaselt. Sellele osutab muuhulgas asjaolu, et mitmeid neist hakati austama juba enne, kui kirik nad kanoniseeris (vt Kirkinen 1987: 141-142). Rahvapärasusele viitab ka see, et paljud neist pühakutest olid oma tausta poolest kohalikud talupojad - või vähemalt 
neid kujutati sellistena (Vlassov 1990-91: 29-30). Pelgalt juhus on vaevalt seegi, et nende pühakute kultuse tugevnemine sattus samasse ajajärku kiriku tugeva kriitikaga «paganlike» rituaalide suhtes. Pühakute austamises võib näha kohalike inimeste püüet näidata ametlikule kirikule karjalaste õigeusklikkust, ortodokslust. Seda võib mõista ka kui kaitsereaktsiooni Moskva riigi pürgimusele võtta tugevamasse haardesse riigi kõige kõrvalisemad piirkonnadki, samuti suurte linnade nagu Novgorodi püüdele tugevdada majandussidemeid perifeeriaga ja korvata sundmaksustamine kauplemisega (vt Vlassov 1990-91: 27). Samal ajal tähendas pühakutekultus karjalaste endi elus sedasama mis «paganlik» teenimine: selle abil kindlustati näiteks saagi õnnestumine või karja ning inimeste heaolu (vt Vlassov 1990-91: 26).

\section{Rootsi surve alt vene unustusse: pärimuse säilimine (17. ja 18. sajand)}

Venemaa ja Rootsi vahel 16. sajandi lõpul ja 17. sajandi algul peetud sõdade tulemusena läks Laadoga-Karjala (Käkisalmi lään) Rootsi võimu alla. Religioosselt oli Rootsis tollal nn luterliku ortodoksia ajajärk ja niisiis suhtuti õigeusklikest elanikkonda juba põhimõtteliselt eelarvamusega. Neid peeti «paganateks» ja poliitiliselt ebausaldusväärseiks, «venelasteks», kuna nad olid sõdades üldiselt toetanud vene vägesid. Sellepärast peeti aateliselt ja poliitiliselt otstarbekaks nende pööramist luterlusse.

Ümberpööramiseks kasutati ennekõike administratiivset survet. Käkisalmi lään oli kirikuvalitsuslikult juba 1578. aastal liidetud luterliku Viiburi piiskopkonnaga. Rootsi lõpliku võidu järel (1617) määrati, et Laadoga-Karjala õigeusklikud peavad osalema luterlikel jumalateenistustel, maksma kümnist ka luterlikule pastorile ja ehitama oma alale luterlikke kirikuid.

Neil keelati endale uute preestrite hankimine Venemaalt ${ }^{3}$ ja neid painutati erinevate materiaalsete hüvituste abil pöörduma luterlusse (Kirkinen 1979: 107-109).

Sunniviisiline luterlusse pööramine siiski ei õnnestunud ortodokside jõulise vastuseisu tõttu. Alles Venemaa ja Rootsi sõda aastail 1658-1661, millega seoses suur osa Laadoga-Karjala ortodoksidest põgenes Venemaale, ${ }^{4}$ ja sellele järgnenud luterlaste massiline ümberasumine Laadoga-Karjalasse muutis religioonidevahelised jõuvahekorrad luterlaste kasuks. Selle järel ei püütud ortodokse enam sunniviisil ümber pöörata. Ilmselt oodati, et nad vähehaaval sulavad rahvastiku enamuse hulka ja võtavad omaks selle usutunnistuse. Viiburi piiskopkonna vaimulikkondki näib olevat 17. sajandi lõpul vaid imestanud ortodoksidest karjalaste «ebausuliste» kommete üle - nagu risti kandmine kaelas või ikoonide austamine (Kirkinen 1979: 113).Teiselt poolt sisaldas muu-usulisus luterliku ortodoksia ajal ohtu, et selle esindajat võidi süüdistada ebausutempude tegemises ja mõista süüdi nõiduses. Ingerist näiteks teatakse paljusid selliseid juhtumeid (vt Laasonen 1984). Karjalaski käidi kohut, kuid lausa surmaotsuseid - mida Ingerimaal võidi arvatavale nõidumises süüdiolijale langetada - ei mõistetud.

Taigade harrastamine, täpsemalt öeldes loitsudest abi otsimine, näib Raja-Karjalas olnud 17. sajandil üldine, sõltumata konfessioonist. Ajaloolane Erkki Kuujo (1963: 187-188) tsiteerib oma Rootsi võimu aegse Raja-Karjala sündmusi käsitlevas uurimuses kohtuprotokolli, mille kohaselt Salmi kohtus süüdistati 1687. aastal sinna paikkonda 16 aastat tagasi Lõuna-Savost asunud seppa Antti Vannist nõidusvõtete kasutamises. Kohtumõistmise ajal Vanninen seletas, et olevat «lugenud soola peale Meie isa palve, usutunnistuse ja muid palveid», ning mõned muud isikud seletasid, et «neis paikades olevat üldiselt kombeks lugeda õnnetusjuhtumi puhul [loits] näiteks hobuse nikastatud jalale». Sepp tunnistas lisaks, et on keetnud rohust ja ürtidest mitmesuguseid võideid inimeste ja hobuste parandamiseks.

Ka mujalt Käkisalmi läänist on samast ajajärgust teada samalaadseid näiteid rahvausundi kohta. Kuujo jutustab eespool nimetatud teoses (1963: 194) kohtuprotsessist, kus käsitleti 
Suistamo Koitonjärvel elava luterlase Yrjö Sikase juhtumit. Sikanen oli läinud otsima (luterlasest) rahvaarstilt abi oma jalahädade vastu. Rahvaarst seletas, et «viga on tulnud sellest vene ristist, mis oli [Sikase maja] lähedal». Sikanen põletas risti. Selle tulemusel algatas kohtuasja risti püstitaja, Sikase ortodoksist naaber, ilmselt karjalane, kaevates, et ta ei saanud «kasutada risti vabalt vene usu kohaselt». Rootsi ja Venemaa 1661. aasta rahulepingu kohaselt oli tal usuvabadus. Kohtus mõisteti Sikasele kahekordne trahv: esiteks nõidususu pärast (loitsijalt abi otsimine), teiseks naabri omandi hävitamise pärast.

Suur Põhjasõda (1700-1721), mil Rootsi üritas laiendada oma maa-alasid Baltikumis ja Karjalas Venemaa arvel, kuid sai lõpuks kaotuse osaliseks, tähendas suurt muutust ka LaadogaKarjala elanikele. Nii ilmalik kui kiriklik võim püüdsid seal sõja järel tugevdada oma positsiooni. See sündis üldjuhul käsikäes, kuna tsaar Peeter I oli 1721. aastal teinud lõpu patriarhi ametile Vene kirikus ja rajanud selle asemele Kõigepühama valitseva sinodi. See oli praktiliselt - kõiges muus peale puht-teoloogiliste küsimuste - valitseja järelevalve all olev ja tema tahet täitev riigi ametkond.

Teateid Karjala ortodokside rahvapärasest vagadusest on 18. sajandist vähe. Kui maaviljelus ja karjapidamine 18. sajandil tugevnesid ja said karjalaste majanduselu aluseks, siis oletatavasti tugevnes ka nendega liituv uskumusmaailm jahindust ja kalapüüki puudutavate kujutelmade arvel. Karjala rahvausundile või selle muutustele ei pööratud Venemaal sel ajal mingit tähelepanu, kuigi piirkond paiknes lausa riigi uue pealinna, Peterburi külje all. See johtus arvatavasti kahest peapõhjusest. Vene valitsejad, eriti Peeter Suur ja Katariina Suur olid ratsionalistid, keda huvitas rohkem oma alamate lojaalsus kui nende religioossed arusaamad. Rahvausund ei olnud ohuks valitseja võimule, pigemini nähti seda idealiseerituna «õilsa metsluse» raamides (vt Sihvo 1973: 32-36).

Ametlikul kirikul taas oli vähemalt kolm rahvausundist suuremat probleemi. Üks oli 17. sajandi lõpul sündinud, vanausulisuse nime all tuntud kiriku lõhenemine (selle kohta vt Laitila 1995). Teine oli kiriku eespool nimetatud alistamine riigile ja kolmas üldine religioosne harimatus, mille kiriku juhtkond teadvustas probleemina eriti 18. sajandi lõpupoolest alates. Kuigi viimatimainituga liituski mitmel kombel rahvausund, olid kiriku võimalused laiaulatusliku õpetamistöö alustamiseks väljaspool suuri keskusi 18. sajandil väga piiratud ja õpetajaist endistki oli suur puudus (vt Freeze 1990). Niiviisi võis rahvausund Karjalas 18. sajandi lõpuks kristalliseeruda selliseks käsituste ja toimingute süsteemiks, millisena seda tuntakse 19. sajandist.

\section{Õitsengust kirikliku usu võimu ja kriitika alla: rahvapärane usuelu autonoomia ajal (1809- 1917).}

Kristalliseerunud karjala rahvausundi põhijooneks võib pidada arvamust, et igal elualal näiteks karjakasvatusel, maaviljelusel või jahipidamise eri aladel - on nagu ka inimesel endal oma «peremees» või «perenaine», oma haldjas; see, keda ortodoksne kirik nimetab pühaks kaitsjaks või eestpalvetajaks (vt Genetz 1870: 92; Haavio 1959; Pelkonen 1965a: 305). Nii näiteks maaviljeluse silmapaistvaim kaitsja oli eriti Vienas ja Aunuses, kuid ka Raja-Karjalas püha Ilja. Uno Harva järgi oli Uhtuas kombeks, et kui alepõletamise alguses ei juhtunud puhuma tuult, siis hakati vilistama ja hüüdma: «Hei püha Ilja, alet põletama!»Vienas ja Aunuses üldiselt ja juhuslikumalt näiteks Suistamos ja Suojärvel oli kombeks viljalõikusel jätta mõned kõrred lõikamata. Neid kõrsi kutsuti Püha Ilja habemeks ja need jäeti põllule, et vili kasvaks hästi ka tuleval aastal (Holmberg 1923: 120).

Ilja võimuses oli rahva arusaamade kohaselt ka ilm. Rahvapärase kalendri järgi lõppes suvi Ilja praasnikuga (20. 7.). Selle pidamise üheks eesmärgiks oli mõjutada Iljad andma pärast 
püha algavaks saagikoristuse ajaks soodsat ilma (Mansikka 1941: 166-167). Rahvavagaduse üks põhimõtteid oli seega vastastikkus: juhul, kui pühakutele (peremeestele, perenaistele) jäetakse midagi, siis tagavad nad viljasaagi (jahisaagi, karja) õnnestumise.

Raja-Karjalas tuntud ohvripeod on oma «paganlikkuse» tõttu Venemaa õigeusu kirikut palju rääkima pannud. Selle ehk kõige tuntumad kirjeldused on pärit Laadoga kirdenurgas asetsevalt Mantsi saarelt. Seal, nagu ka muuseas Suistamos, korraldati 20. sajandi alguseni peaaegu igal aastal iljapäevale järgnenud pühapäeval pühaku auks praasnik, mille kõrgpunktiks oli ohvriliha keetmine ja söömine. Püha eesmärgiks oli kaitsta karja ohtude eest. Sinna kogunes rahvast kogu Mantsist, Salmist ja kaugemaltki (Haavio 1949: 155, 159-160; Harju 1997; Rajamo 1944: 272-273).

Ohverdatava härja kinkis või, nagu tavaliselt kõneldi, «lubas» teatud küla järjekorra alusel. Härg tapeti kas laupäeva õhtul või, rohkemate teadete kohaselt, pühapäeva hommikul. Tapmisega liitus siis ka jumalateenistus, mille pidas kas kohalik preester või üldisemalt keegi ohvritoimingu keskseist isikuist. Tapjaks oli sageli külavanem. Liha keedeti seejärel ühiseks söömaajaks. Nahk müüdi enampakkumisel ja saadud tulu talletati külatsassounas hoitavasse «ohvrivakka». Kohapealne vaimulikkond pidas pidustust paganlikuks ja mõjutas külarahvast kord heaga, kord ähvardustega sellest loobuma. Pidustused jätkusid ometigi ilmselt 1910. aastateni. (vt Haavio 1949: 155-157; Harju 1997; Jääskeläinen 1912; Sauhke 1971: 164-172; Viljanto 1991: 292-295).

Mantsi saare naabruses Lunkula saarel ohverdati nn bokpäeval (4. juulil) oinaid. Pidustuse algupära on hämarusega kaetud, kuid selle eesmärgiks oli tagada lammaste kasvu. Ohvripidustus oli oma vormilt samasugune kui Mantsi saarel. Oinaste tapmine lõpetati ilmselt 1909. aastal, kuid neid kingiti pühapaigale kuni 1930. aastateni (Sauhke 1971: 144-148).

Lunkula saare ohvripidustuste ajaloos võib 19. sajandil märgata selgelt karjala rahvaortodokslusele omaseid jooni. Ilmselt 1820. aasta paiku ehitasid lunkulalased saarele väikese tsassouna. Preester, kes oli venelane, ei nõustunud seda pühitsema, mille peale külarahvas pühitses palvehoone omal käel lammaste kaitsjaks nimetatud pühale Shpuashule [Päästjale, Lunastajale]. Nad hakkasid seal ka palvusi pidama ilma preestrita. Kui pühakoda 1870. aasta paiku remonditi, siis Salmi (karjala sünnipära) preester pakkus ennast pärimuse kohaselt palvehoonet pühitsema ja pühitseski selle Issanda muutmise mälestusele. Külarahva arvamust asja kohta ei küsitud, mispärast nad olevat jutu järgi pahaseks saanud: pühitsemisjumalateenistuse lõpul keeldunud suur osa külarahvast kombekohaselt suudlemast risti, mida preester käes hoidis. Külarahva ja vaimulikkonna suhted olid selle järel pikka aega jahedad (Sauhke 1971: 147-148).

Mantsi saare ja Lunkula saare ohvripühad kujutavad praasnikute teatud üldisi jooni ja eesmärke. Tegemist oli kollektiivse riitusega, mis sidus külaelanikke oma külaga, tegi sellest nimelt nende oma küla. Samal ajal meenutas ohvripüha külainimestele, et karja - ja selle kaudu inimeste - heaolu oli kõikide ühise vastutuse all. Riituse tähendusest külarahvale kõneleb see, et kui Venemaa õigeusu kirik sundis neid ohvripüha lõpetama, loobutigi sellest 1850. aastatel, kuid alustati uuesti pärast seda, kui karu ujus Mantsi saarele ja tegi seal hävitustööd (Haavio 1949: 158).

Külapühade nagu üldisemaltki kalendrirituaalide suur sotsiaalne tähendus on mõistetav, kui mõelda, kuivõrd keskne oli traditsioonilise küla argielus asjade jätkumine samana või inimeste ja koduloomade viljakuse ning viljakasvu tagamine (vt Foster 1965). Ei ole juhus, et näiteks kari lasti karjamaale Jüri, Georgius Võiduka päeval (23. 4.) ja pandi lauta pokrovi, Neitsi Maarja kaitsmise püha ajal (1. 10.) Mõlemad päevad olid nii kiriklikult kui ka pere- 
konna (või suguseltsi) piires silmapaistvad pidupäevad (Sauhke 1971: 270; Timonen 1990: 113), milles tõusis esile pühakute hoolekanne omade eest, nende eest, kes austavad pühakut kohasel viisil.

Iivo Härköse (1920: 135; vrd Haavio 1935: 138-139) järgi koguti jüripäeva eelõhtul kõik algavaks suveks karja jaoks varutud kellad kokku ja pandi «erilisse suurde potti, kuhu kallati vett ja mis asetati aukohale pinkide ristumiskohta pühapiltide alla». Seejärel palvetati pikalt ja siis kandis keegi maja poistest nad päripäeva ümber maja/talu ja kõlistas neid «võimalikult kõvasti, et kostaks teistessegi taludesse». Ringkäiku korrati kolm korda, misjärel kellad toodi tagasi veeanumasse. Hommikul korrati seda veel, enne kui kellad seoti karjale kaela. $\underline{\mathbf{5}}$ Kuna karjakasvatus oli eeskätt naiste ja laste töö, siis oli neil ka keskne osa selles ja muudes vastavates rituaalides (vt Saarikivi 1974: 24-25). Teiselt poolt ka naise madal positsioon ortodoksse kiriku hierarhias, teisisõnu, ta väljajätmine kiriklikest ülesannetest võib seletada, miks rahvaortodoksia üldiseltki säilis just naiste seas.

Kui ortodoksse kiriku ${ }^{\mathbf{6}}$ ja (Soome) riigi haare Raja-Karjalas kasvatuse, hariduse ja halduse abil tugevnes, siis hakkas rahvaortodokslus üldhaarava süsteemina 19. sajandi lõpuks murenema. Esiteks ilmnes see nn inimese eluperioodide rituaalides: sünni, abiellumise ja surmaga seotud tavades. Neis rõhutati 19. sajandi lõpul ja veel enam 20. sajandi alguses endisest rohkem ametliku kiriku õpetusest ülevõetud jooni ja rituaale. Kui näiteks Suojärvi küla laps viidi tervise ja heaolu kindlustamiseks sauna, siis pidi saunaskäik toimuma täpselt teatud rituaalide järgi. Saunatamise ajal paluti lapsele muuhulgas Jumala õnnistust, rahu ja tervist Spoassalt (Lunastajalt), emakeselt Neitsi Maarjalt ja pühalt Iljalt, vee andjalt. Lõpuks õnnistati last lugematuid kordi ristimärgiga haiguste ja õnnetuste vastu (Pelkonen 1965b: 356358; vt ka Genetz 1870: 92-93.)

Kõige selgemini paistis kiriku mõju surmaga seotud tavades. Kõik eluperioodi riitused olid sündmused, mis mõjutasid pere, suguvõsa ja külaühiskonna elu, kuid surma põhjustatud muutus oli korvamatum kui muud. Ilmselt sel põhjusel, kuid samuti ellujäänute heaolu tagamiseks püüti surma lähenedes lahendada kõik surijaga seotud tülid. Oli kombeks, et sugulased ja sõbrad käisid surija juures proskenjalla, andeks palumas, leppimas. Suojärvel ütles paluja: «Prosti roadi Hrista» (Anna andeks Kristuse nimel). Surija vastas: «Jumala prostikkah» (Jumal annab andeks). Lisaks paluti surnu käest andeks veel enne surnuaiale minekut. Teel surnuaiale paluti surnu nimel andeks neilt, keda juhtuti kohtama (Pelkonen 1965c: 367, 369-370; Rajamo 1944: 268).

Surma, surnukeha pesemise, ${ }^{7}$ surnuvalvamise ja matmise järel mälestati Raja-Karjalas kirikliku kombe järgi 40 päeva pärast surmapäeva (kuusnetäliset). Kohati peeti ka külakondade ühist surnute mälestuspäeva (vene radonitsa) ehk surnute ülestõusmispüha. See püha, kirikukalendri järgi Tooma teisipäev, on teine teisipäev ülestõusmispühade järel. Püha juurde kuulus kalmudel käimine - toidu viimine haudadele, kadunute kõnetamine, itkud - ja selle järel suguvõsa mälestussööming kodus. Samalaadne püha oli oktoobri kolmandal laupäeval muistinsuovatta, kadunute mälestuslaupäev (Harva 1932: 478-479; Mansikka 1923; Pelkonen 1965c: 372-373).

Rahvapärane ja kiriklik surmaga seotud pärimus kulgesid siin eriti paralleelselt, kuna ka kiriklikku traditsiooni kuulus olemusliku osana lahkunute mälestamine. Kohe inimese surma järel oli kombeks pidada kadunule nn hingepalve (panihhiida). Öisele surnuvalvamisele kolmandal ööl pärast surma oli tavaks kutsuda preester kadunule palveid lugema. Nende järel lauldi ühiselt kirikulaule, mille vahel preester pidas kadunu mälestuseks kõne. Järgmisel päeval surnu maeti. $\underline{\underline{8}}$ 
Kuusnetäliset olid ühtlasi ka kiriklik püha, sest siis peeti lounaallinen, liturgiline jumalateenistus lahkunule. Teenistuse järel käidi kalmistul pidamas lahkunu eest litaaniapalvust. Ka surnute ülestõusmispühade ajal ja mälestuslaupäeval käisid vaimulikud surnuaial litaaniat toimetamas (Rajamo 1944: 268-269).

Kirikus palvetati samuti lahkunud lähedaste eest. Selle jaoks paigutati nende nimed erilisse mälestamisraamatusse. Rajamo tõdeb, et Suistamo mälestamisraamatust võis leida «selliste omaste nimesid, kes olid surnud koguni saja aasta eest. Isegi nii pikalt võis palveelu kaudu säilida side elavate ja lahkunute vahel» (Rajamo 1944: 220).

Samasugune igavikuperspektiiv kuulus ka palverännakute juurde, kus kiriklik ja rahvapärane usuelu jälle kohtusid. Raja-Karjala ja Lõuna-Aunuse keskseim palverännaku sihtkoht oli autonoomia ajal Valamo klooster. Sinna mindi sageli suure hulgaga, tihti külade kaupa. Eeskätt Salmist tehti palverännakuid ka Süvari Aleksandri kloostrisse Süvari jõe lõunarannal eriti Püha Kolmainu päeval ehk nelipühadel. Kloostri peakirik oli pühitsetud Pühale Kolmainule ja kloostris oli siis suur püha, mille ajal tehti ka palju hobustekaupa (Sauhke 1971: 512).

Palverännakule minekuks oli rohkesti põhjusi. Paljud olid Jumalale või pühakule mingis raskes olukorras, kasvõi haiguse puhul andnud lubaduse: kui sellest pääsen, käin Valamos. Niisuguseid lubadusi nimetati jiäksiminen või jääksiminen. Mõningatele oli rännak patukahetsusmatk, lepitus pahategude pärast. Osa läks teekonnale ilmselt uudishimust, et näha kuulsat paika ja selle hiilgust või imettegevaks nimetatud ikooni. Polnud harvad juhtumid, et Valamos käidi kaugeltki igal aastal korra (vt Härkönen 1928: 228-229).

Praasnikud, mälestuspäevad ja palverännakud olid tähtsamaid rahvaliku usuelu väljakujunenud vorme. 19. sajandi lõpuks üha jõulisemalt rahvusliku meelsuse omandanud luterlik Soome, samuti kui soomemeelsed ortodoksidki, nägi karjala rahvapärases ortodoksluses siiski liialt venepärasust või, mis neile oli umbkaudu sama asi, ebausku (vt Genetz 1870). Seda rahvapärast usuelu ei peetud selle tõttu ehtsaks või õigeks karjala «rahvahinge» ilminguks, vaid viimaseks peeti (või sellena rõhutati) kalevalavormilist rahvaluulet, eriti «Kalevalat» ja selle esitamist.

Kuigi kalevalavormilise pärimuse maailm polnud ortodokssetele karjalastele loomulikult võõras, polnud see ometi nende usuelu keskne osa. Karelianistide ja muude soome rahvusromantikute (vt nende kohta Sihvo 1973) mõjul sai kalevalavormilise rahvapärimuse oskajaist nagu ka itkude esitajaist ja kandlemängijaist kummatigi 19. sajandi lõpust alates muuhulgas mitmesuguste külapühade olemuslik osa. Ka pulmad ja matused olid olukorrad, kus vana rahvalaul ja selle oskajad olid au sees. Teravdatult võib väita, et runolauljad tõukasid kõrvale karjala rahvaortodoksse usuelu. Rahvapärane ortodokslus, mis oli oma hõlma all säilitanud vana runopärimuse (vt Nenonen \& Rajamo 1955: 299), pidi nüüd sulama «ehedasse» karjala rahvapärimusse. Naasen selle juurde allpool.

Autonoomia aja lõpul elasid nii runod kui rahvaortodokslus mingi aja kõrvuti, kumbki oma nishis. Ortodokslus valitses koduringis ja vana runolaul kodust ning külast väljaspool olevas maailmas, samuti kriisiolukordades (vt Nenonen \& Rajamo 1955: 299-300). Pärimused liitusid suurte pühade nagu jõulude ajal. Siis oli näiteks Salmis kombeks minna slaavima (kiitma). See sündis esimesel jõulupühal, mil majast majja käis slaavijaid üksikult või väikeste rühmadena. Nad küsisid ukse peal peremehelt luba slaavimiseks. See saadud, läksid nad pühasenurka, tegid ristimärgi ja hakkasid laulma kirikuslaavi keeles ortodoksset jõulukaanonit «Kristus sünnib, kiitke». ${ }^{9}$ Hümni järel esitati kodukootud kirikuslaavi keeles pika ea ja rõõmsate pühade soov (Sauhke 1971: 351). 
Siin, nagu allpool kõne all olevas smuuttiks käimises, oli lõppude lõpuks tegemist laialt tuntud päikese ringkäigu, talvise pööripäeva ja aastavahetusega seostuva kriisiriitusega (vt Eliade 1993).

Rahvapärane ortodokslus ei ilmnenud siiski ainult kommetes. Selle maailmapilt oli rüütatud ka sõnalistesse vormidesse, millest tähtsaimad olid legendid. Neis oli keskne asend eetilisel õpetusel - ja sellega seoses sotsiaalsel kontrollil, õigele teele juhatamisel. Tähtsaimad RajaKarjala legendides esinevad põhimõtted võib kokku võtta järgmistesse mõistetesse: õige teguviis, usaldus ja ime.

Õige teguviis tähendab teiste inimeste arvestamist ja aitamist. Legendides tuleb korduvalt esile muuseas see, kuidas tundmatu kerjuse omakasupüüdmatu abistamine tasutakse ja kuidas aitamata jätmisele järgneb karistus. Niisamuti kordub legendides Hiiobi saatus, süütu kannatamine. Karu sõi näiteks vaese, vaga lesknaise lehma, ükskõik kuidas lesk palvetas. Teiselt poolt õige teguviis ja usaldus Jumala ning pühakute vastu õnnetustegi ajal lõpuks tasuti: sündis ime. Torm vaibus, vili andis mitmekordse saagi, haige paranes. (Järvinen 1994; vt ka Razumova 1996). Karjala legende palju uurinud folklorist Irma-Riitta Järvinen tõdebki kokkuvõtvalt, et neis rõhutatakse samasugust eetilist õpetust nagu Bütsantsi ja slaavi pühakute elulugudes, üleskutset toimida oma ligimese heaks. (Järvinen 1994: 12). Niisiis võib öelda, et rahvapärane ja kiriklik eetika moodustasid terviku, milles sama teemat, hea ja kurja, õige ja väära probleemi käsitleti kahe erineva, kuid üksteisega liituva ja kõrvuti elava kogemusmaailma põhjal (vrd Pelkonen 1965a: 303-305).

Kirikliku ja rahvapärase kogemusmaailma vahel valitses ometi kogu aeg ka vastuolu. See nähtub kasvõi sellest, et Karjala vaimulikkond kritiseeris - eriti 20. sajandi algusest alates oma väljaannetes nagu ajakirjas «Aamun Koitto» rahva «ebausulisi arusaamu» (näiteks AK 2/1907: 17). Niisamuti määrasid preestrid epitiimiaid, vaimulikke karistusi, teguviiside eest, mida peeti ebausuks. Nõnda määras Suistamo esipreester Johannes Sitikov (preester 18881897) perenaisele Maria Patrikkale 100 maani kummardust (palvet) sellepärast, et «ta oli ebausklik ja oli loitsinud ühele talupidaja tütrele ruani [mingi tõbi] sõnu ja loitse» (Rajamo 1944: 276).

Kokkuvõtteks võib tõdeda, et autonoomia aja lõpul oli Karjala rahvalik ortodokslus sattunud surve alla. Ortodoksne vaimulikkond püüdis tugevdada kiriku ametlikku asendit nii rahva seas kui ka luterluse suhtes. Sellepärast üritas ta välja juurida arusaamu ja tavasid, mis ei olnud kooskõlas kiriku ametliku õpetusega. Selles võitluses leidis ta endale liitlase rahvusliku meelsusega soomlaste näol, kes samuti soovisid välja juurida rahvapärast ortodoksset usuelu, mitte küll selleks, et valmistada pinda «ehtsale» ortodokslusele, vaid et leida «ehtsat» karjalapärasust. Preesterkonnale oli rahvavagadus soome ortodoksluse, rahvuslastele karjalaste soomluse takistus. Käsitlen lõpuks lühidalt Karjala rahvaortodoksluse käekäiku iseseisva Soome esimestel kümnenditel푸 ning sellele samal ajajärgul pärimuse uurijate poolt suunatud kriitikat.

\section{Pärimus võidab usu: rahvalik usuelu 1917-1939}

Ortodoksse kiriku vaimulikkonna pürgimus pöörata karjalaste rahvapärane ortodokslus tagasi kiriku ametliku õpetuse voolusängi tähendas tähelepanu keskendamist eriti naise ülesannetele. Rahvapärase usuga kaasaskäivate rituaalide toimepanijaist püüti teha, ja tehtigi, kiriklikult heakskiidetavama koduse usuelu ja laste usulise kasvatuse korraldajad (vt näiteks AK 21-22/1928: 247; Saarikivi 1974). Ortodoksluse vene tausta asemel rõhutati usu karjalapärasust «igavestest aegadest». Samal ajal rõhutati - ehk mitte niivõrd karjalastest ortodokside endi keskel kui Soomes üldiselt - karjalaste keelelist ja rassilist soomepärasust ning 
Venemaad kui nende «alatist» vaenlast (vt Mikkola 1932). Eriti Soome «valge» juhtkond tahtis poliitilistel põhjustel igat moodi lahutada karjalasi venelastest, keda peeti eranditult «punasteks» (vt Frilander 1995).

Rahvavagaduse vastu suunatud mitut laadi surve üks tagajärg oli traditsiooni killunemine tavadeks, mille sügavam tähendus hõlpsasti hämardus. Üks näide sellest on niinimetatud smuuttiks käimine jõulu ja kolmekuningapäeva vahel. See komme oli üldine kogu ortodoksses Raja-Karjalas (vt Jänis 1997; Nenonen \& Rajamo 1955: 79). Matti Jänis (1997) jutustab, et Tulemas, Salmi kihelkonna peakülas, «kamp noori tüdrukuid ja poisse leppis omavahel kokku teatud õhtu, millal minna külla käima smuuttina majast majja. [---] Noored riietusid veidratesse riietesse, selliselt, et neid mitte keegi ära ei tunneks. [---] Läksime rändama ülemeelikult rõõmsaina ja valjusti lärmates - pillimees mängis kasvõi suupilli ja mõned lõid «trummi» ehk puupulgaga tühja plekkpurgi põhja.»

Smuuttid koputasid kõvasti uksele ja küsisid: «Kas võime tulla smuuttiks?» Harva lükati palve tagasi. Majas sees pillimehed mängisid ja ülejäänud tantsisid ja katsusid häält moonutades laulda. Pererahvas üritas smuutte ära tunda (Jänis 1997).

Smuutti-traditsioon oli Jänise järgi noorte vallatu koosolemine. Teiste teadete järgi (Salmi kunstniku Pirkko Jauhiaise suuline teade) oli sellega seotud ka rohke alkoholi tarvitamine. Smuuttiks käimist jätkati veel mõnda aega pärast Teise maailmasõja lõppugi. Pole teada, et sellel oleks olnud mingit kiriklikku seost. Tundub ilmne, et see oli teine versioon samast rahvusvahelisest «karnevalismist», mille kiriklikumale versioonile, slaavitamisele, viidati eespool. Eesmärgiks oli selgi puhul kindlustada, et tulev aasta oleks hea. $\underline{\underline{11}}$

Eelkirjeldatu kõrval elas 1920. ja 1930. aastail mitmel viisil toetatud «kalevalaline rahvapärimus», kogum tavasid, mille esitamist toetasid kõige silmatorkavamalt rahvusromantiline, peaasjalikult luterlik haritlaskond ja turismindus. Ortodokssed karjalasedki toetasid üldiselt samuti selle pärimuse esitamist. Näiteks Suistamo pulmades oli 1920. ja 1930. aastatel «itkejaid ja runolauljaid õnne (lykkyö da osua) soovimas» (Nenonen \& Rajamo 1955: 79). «Surnuvalvamist peeti lahkunu kodus kolmel ööl. Siin lauldi vaimulikke laule, loeti Piiblit, jutustati suakkuna'id, itkejanaised itkesid «teise ilma mineja» mälestuseks. Matuste-eelne öö valvati täielikult, siis ka söödeti ja joodeti rahvast. Kalmistule minema hakates esitasid itkejad «saatmisitke». [---] Kadunute mälestust austati eriti pühana ja «kalmulkäimised», «lounuallised» 'päevajumalateenistused' ja muud mälestamised peeti ettenähtud ajal. [ ] Pühapäeva- ja pühadeaegne töö oli suur patt. Pühapilt (obrasa) pidi olema 'suures tshupus' (pühasenurgas), majja tulles pidi tegema ristimärgi, samuti sööma istudes ja söömast tõustes.» (Nenonen \& Rajamo 1955: 79-80).

Sellest kirjeldusest võib juba näha, kuidas rahvaortodokslus ja kalevalaline pärimus hakkasid moodustama oma, «karjala» pärimust. 12 Sellest on teada palju muidki näiteid. Eliel Wartiaise (1953: 131-133) järgi Korpiselja Tolvasjärvel - nagu üldiselt ortodoksses Karjalas - oli kalmistu püha paik. Kui mõned külaelanikud olid langetanud kalmistul igivanu puid - eesmärgiks oli ainult mahalangenud kask ära vedada -, siis kaks puulangetajat olid raskesti haigestunud ja teine neist suri. Wartiaise järgi usuti üldiselt, et «see oli karistus pühitsetud paiga, nii Jumala kui haldjate solvamise eest».

Wartiaise informant Hannes Wornanen jutustas ka, et surnuaia lähedal oli omal ajal olnud suur puurist. «Kui tuli mõni väiksem häda, haav või haigusjuhtum, siis mindi muude toimetuste vahepeal risti juurde, viidi ehk väike kingitus ja 'molittiin', palvetati. Räägitakse, et preester viinud risti minema, sest see oli jutu järgi ka «paganlik» haldjatele ohverdamise paik.» (Wartiainen 1953: 132). 
Koos kalevalalise pärimuse austamisega tõusis (ja tõsteti) rahvalikus usuelus esile uus spetsialistide rühm - rahvaarstid. Neid oli teadagi olemas olnud vägagi kaua, kuid kui muud rahvaliku usueluga seotud rituaalide teostajad, nagu teadjad, kalapüügi, jahi ja karjakasvatuse riituste tundjad, kaotasid paljudel põhjustel oma positsiooni, siis rahvaarstid jäid ja neilt otsiti abi, kui mitte muidu, siis viimase vahendina selle järel, kui arstidestki polnud aitajaid (vrd Genetz 1870: 92-96).

Rahvaarstid olid veel 1920. ja 1930. aastatel Raja-Karjalas tavalised. Mauno Pehkoranta näiteks jutustab oma lapsepõlve Suistamo Koitto külas meenutades, et «Törttö buabo, Matjoi Simanainen, ja Mäki-buabo olid parandajamemmed. Armastuse äratamine ja muu säärane oli ka nende käes. Kuljukka Jehimä oskas päästa metsa eksinud lehmi, kutsuda karu raipe juurde jne» (Nenonen \& Rajamo 1955: 78).

Rahvaarstimiseski astuti teinekord rahvaliku ortodoksluse piiridesse. Seal oli vahe haldjate ja ametliku kiriku pühakute vahel sageli juuspeen. Suistamo Loimolas jutustatakse 20. sajandi algul perenaisest, kes oli kannatanud paar nädalat kõva hambavalu ja palunud paranemist pühalt Gabrielilt, kes oli maalitud tema pühasenurga ikoonile. Kaks nädalat asjata palvetanud, sai perenaine vihaseks: ta läks nurka, rebis ikooni lahti, viis selle välja ja tõukas - oli parajasti talv - hange, öeldes: «Mine ära, Gavril, pole sa mind kunagi aidanud!» Loo jutustanud Wartiainen (1953: 137-138) lisab: «Ei ole vist raske arvata, et haigusest lahti saanud eit kandis Gabrieli tagasi oma paigale tares ja palus põlvitades ning pisarates andeksandmist.»

Rahvaluuleuurija Martti Haavio (1935: 140-143) omalt poolt jutustab Suojärvel elanud Ontreist, kes «uskus jätkuvasti haldjaid» ja oskas suure hulga loitse. Kui Haavio lõikas pliiatsit teritades sõrme, siis luges Ontrei vere kinnipanemise sõnad, sülgas, luges loitsu ja sülgas veel kolm korda «ja väitis siis, et see võtab kindlasti valu ära ja sulgeb vere». Haavio kirjeldab ka Ontrei ravivõtteid (loitse) kärnade ja rõugete vastu, kuid tema väljendusviisist võib hõlpsasti märgata, et ta ei hinnanud Ontrei teadmisi ja oskusi kuigi kõrgelt. Samasugune seisukoht on tüüpiline ka teistele rahvuslikult orienteeritud soomlastest karjala pärimuse uurijaile. Võibki väita, et nemad, igatahes rohkem kui ortodoksikirik, andsid viimase, aatelise hoobi rahvaortodokslusele. Pärimuseuurijad otsisid ja imetlesid «ehtsat» kalevalalisust. Põhjustel, mis on liiga ula-

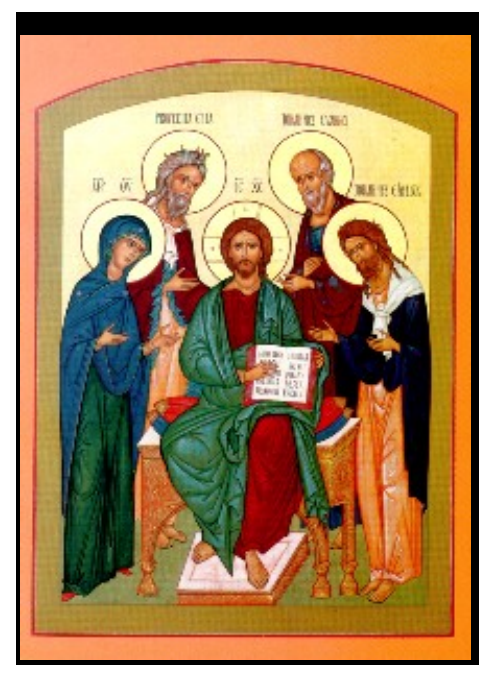
tuslikud siin vaatlemiseks, ei olnud nad huvitatud eeskätt Raja-Karjalast, vaid kalevalapärase traditsiooni «hällist», Vienast ja Aunusest. Ometi puudutas nende «karjalapärase» rahvausundi kriitika põhimõtteliselt ka ortodoksset Raja-Karjalat.

Üldiselt võttes arvustasid pärimuseuurijad karjala rahvausundit välispidistes toimingutes kinniolemise pärast. Samuti kritiseerisid nad luterlusest erinevaid institutsioone, pidades neid põhisüüdlasteks selles, et «vene mõjud» elasid jätkuvalt karjalaste seas, eriti Vienas ja Aunuses. T. I. Itkonen näiteks loetleb teose «Suomen suku» teises osas paljusid kloostreid ja eraklaid Süvarist Solovetsini. Need paigad olid tema järgi Karjala keskseim ala. Selle ortodokslus oli Itkose meelest pinnaline, mitte ehtne religioossus, kuna «vene usk» oli väljastpoolt toodud asi, mis oli omaks võetud elupraktika sunnil. Itkonen ei näi olevat mõtelnud, et rahvalik orto- 
dokslus oleks võinud olla tõeline, karjalaste elu orgaaniline osa. Ta mõistis seda pigem mingisuguse eesriidena, mis varjas enda all «ajatut», igavesti «samana» ilmnevat karjala rahvausundit (vt ka Genetz 1870: 84-85).

Karjala ajalugu ja kultuuri ulatuslikult tutvustanud «Karjalan kirja» ('Karjala raamat') 1932. aastal ilmunud teises trükis vaatles usundiloolane Uno Harva Itkosest ulatuslikumalt karjalaste usundit, alates eelkristliku ajajärgu uskumustest. Karjalaste muinasusu tuuma moodustas Harva järgi teadja-institutsioon (ravimine, loitsimine jne), pühade paikade, nagu kalmistud ja hiied, ning nende haldjate (peremeeste) austamine. Ta viitab sel puhul Novgorodi peapiiskopi Makari esitatud teadetele.

Ka Harva järgi oli Karjala - mille all ta mõtleb Vienale ja Aunusele lisaks ka Raja-Karjalat ortodokslus pinnaline, kristlike terminitega vabalt tõlgitud muinasusk. Karjalas üldiselt tuntud püha Ilja oli asendanud muinasusundi Ukko, karjahaldja asemele olid tulnud püha Jyrki 'Jüri', püha Ulassie ehk Valassi (Blasius), püha Miikkula ja paljud muud. Pühasid hiisi on pühade ohvri- ja palvepaikadena asendanud kirik või palvekoda, tsassouna.

Harva nägemus pole nii üheülbaline nagu Itkose oma. Ortodokslus on tõepoolest tulnud Karjalasse mujalt, kuid karjalased on seda kujundanud omal kombel. Kuigi karjalane ei oskaks vastata küsimusele, miks ta õigupoolest palvetab kasvõi püha Miikkula poole, nagu Itkonen (1928) väitis, ei tähendanud see Harva järgi seda, et pühakute palumine oleks karjalastele pelgalt sotsiaalse tähenduseta komme.

Itkose kombel nägi Harvagi lõpuks ometi ortodoksluse olevat karjalastele võõra asja, millegi, mis peitis enda all nende ehtsat usundit, kalevalalist rahvausundit. Niimoodi püüavad mõlemad uurijad lõpuks seletada väljaspoolsete mõjudega seda, mis eristas karjalasi soomlastest. Rahvapärane ortodoksluski, mida ei saa pidada karjalastele võõraks elemendiks, muutus niiviisi tõrjutuks ideoloogiliste põhjendustega: soomlases - ja soomlasteks karjalasi peeti - ei tohtinud olla venelase poole viitavatki. Hilisem uurimistöö on korrigeerinud seda nägemust (vt Timonen 1990: 117), kuid ideoloogiline pinge rahvapärase ja ametliku ortodoksluse või luterluse ja «ehtsa» ning «ebaehtsa» rahvapärimuse vahel on jätkuvalt olemas.

Tõlkinud Kristi Salve

Kirjandus

Aamun Koitto 1896 - Kuopio. Perioodiline väljaanne, aastast 1922 Soome ortodoksse kiriku hääljekandja.

Ambrosius (munkki) 1981. Luostarilaitos Karjalassa. Karjala 1. Portti itään ja länteen. Toim. YrjöPekka Mäkinen \& Ilmari Lehmusvaara. Hämeenlinna: Karisto.

Augustin (Nikitin), arkkimandriitta 1991. Suur-Novgorod ja ortodoksinen lähetystyö (1000-1500luku). Taipaleen ortodoksinen seurakunta 400 vuotta. Toim. Stefan Holm \& Markku Toivanen. [Taipale:] Taipaleen ortodoksinen seurakunta, 1k 25-55.

CN 1970 = The Chronicle of Novgorod 1016-1471. Tr. from the Russian by Robert Michell \& Nevill Forbes. New York: AMS Press.

Eliade, Mircea 1980. History of religions and «popular» cultures. History of Religions, vol. 20 (12), 1k 1-26.

Eliade, Mircea 1993 (1949). Ikuisen paluun myytti. Suom. Teuvo Laitila. Helsinki: Loki-Kirjat. 
Foster, George 1965. Peasant society and the image of limited good. American Anthropologist 67 (2), lk 293-315.

Freeze, Gregory L. 1990. The rechristianization of Russia: The church and popular religion, 17501850. Studia Slavica Finlandesia 7, lk 101-136.

Frilander, Timo 1995. Valtiovalta, venäläiset ja kalenterikysymys 1917-1923., Ortodoksia vol. 44, lk 56-84.

Genetz, Arvid 1870. Kuvaelmia kansan elämästä Salmin kihlakunnassa. Koitar I, 1k 84-109.

Haavio, Martti 1935. Kuvia Raja-Karjalan muinaisesta henkisestä kulttuurista.Vanhan runon mailta. Raja-Karjalan Säätiön julkaisuja 2. Porvoo \& Helsinki: WSOY, lk 133-176.

Haavio, Martti 1949. Karjalainen hekatombi. Kotiseutu, vol. 40, lk 153-161.

Haavio, Martti 1959. Karjalan jumalat. Porvoo \& Helsinki: WSOY.

Harju, Anne 1997. Pyhän Iljan praasniekka. Laatokan Mantsi, härkäuhrin saari. Toim. Valto A.

Peiponen. Lappeenranta: Karjalan Kirjapaino Oy, lk 105-117.

Harva, Uno 1932. Karjalaista kansanuskoa ja palvontaa. Karjalan kirja. Toim. Iivo Härkönen.

Toinen, kokonaan uudistettu painos. Porvoo \& Helsinki: WSOY, lk 469-482.

Holmberg [Harva], Uno 1923. Pyhän Iljan parta. Suomi. Kirjoituksia isänmaallisista aiheista. V:2.

Helsinki: Suomalaisen Kirjallisuuden Seura.

Huovila, Marja 1995. Käkisalmen läänin vaiheita esihistoriasta vuoteen 1811. Lahti :[Käkisäätiö].

Härkönen, Iivo 1920. Itäinen vartio. Lukuja vanhasta Karjalasta. Helsinki: Otava.

Härkönen, Iivo 1928. Runon hirveä hiihtämässä. Hupainen ja tosi kertomus nuoren miehen

matkoista. Porvoo: WSOY.

Itkonen, T. I. 1928. Karjalaiset. 6: Uskonto. Suomen suku II. Toim. A. Kannisto et al. Helsinki:

Otava, lk 17-22.

Jänis, Matti 1997. Smuutat - eli kummittelijat. Nuori Karjala, vol. 62 (1), lk 4-5.

Järvinen, Irma-Riitta 1994. Karjalaisten legendojen eettiset opetukset. Aamun Koitto, vol. 88 (11), 1k 11-13.

Jääskeläinen, Viljo 1912. 'Bokin' päivä Salmin Lunkulassa. Kotiseutu, vol. 3, lk 156-158.

Kirkinen, Heikki 1979. Ortodoksisen kirkon varhaisvaihe Suomessa. Ortodoksinen kirkko

Suomessa. Toim. isa Ambrosius \& Markku Haapio. Lieto: Etelä-Suomen Kustannus Oy, lk 88-116.

Kirkinen, Heikki 1987. Bysantin perinne ja Suomi. Kirjoituksia idän kirkon historiasta. Joensuu:

Ortodoksisen kirjallisuuden julkaisuneuvosto.

Kirkinen, Heikki 1995. The founding of the Valamo monastery: When, how and by whom.

Ortodoksia, vol. 44, lk 30-55.

Kuujo, Erkki 1963. Raja-Karjala Ruotsin vallan aikana. Joensuu: Karjalaisen Kulttuurin

Edistämissäätiö.

Laasonen, Pentti 1984. Kristillistyvä talonpoika. Sukupolvien perintö 1. Espoo: Kirjayhtymä, lk 295-322.

Laitila, Teuvo 1995. Vanhauskoisuus. Venäjän kirkon 1600-luvun hajaannuksen taustahistoria ja alkuvaiheet. Teologinen aikakauskirja, vol. 100 (4), lk 308-317.

Makari $=$ Makary (archimandrite) 1989. The Life of St. Makary, Metropolitan of Moscow and all Russia. The Journal of the Moscow Patriarchate 6/1989, lk 54-61.

Mansikka, V. J. 1923. Eräs inkeriläis-itäkarjalainen vainajainjuhla. Suomi. Kirjoituksia isänmaallisista aiheista, V:2. Helsinki: Suomalaisen Kirjallisuuden Seura, lk 173-184.

Mansikka, V. J. 1941. Katolisia pyhimyksiä Suomessa. 2. Maanviljelyksen suojeluspyhimykset. Kotiseutu, vol. 42 (4), lk 164-174.

Mansikka, V. J. 1967 (1921). Die Religionen der Ostslaven I. Quellen. (FFC nro 43.) Helsinki:

Suomalainen Tiedeakatemia. Zweite Auflage.

[Mikkola, J. J.] 1932. Vienan, Aunuksen (ja Vepsän) historiaa. Karjalan kirja. Toim. Iivo 
Härkönen. Toinen, kokonaan uudistettu painos. Porvoo \& Helsinki: WSOY, 1k 228-260.

Nenonen, Väinö \& Rajamo, Mikael (toim.) 1955. Suistamo. Muistelmia ja kuvia kotiseudustamme.

Pieksämäki: Suistamon pitäjäseura.

Ohhotina = Okhotina, Natalia 1993. The Tale of the Valamo Monastery. Ortodoksia, vol. 42, 1k 89135.

Pelkonen, Lauri 1965a. Suojärveläisistä ja heidän sivistyksestään. Suojärvi I. Toim. Lauri Pelkonen. Pieksämäki: Suosäätiö, lk 293-314.

Pelkonen, Lauri 1965b. Lapsi syntyy taloon. Suojärvi I. Toim. Lauri Pelkonen. Pieksämäki:

Suosäätiö, lk 353-366.

Pelkonen, Lauri 1965c. Kuolemaan liittyvät tavat ja uskomukset. Suojärvi I. Toim. Lauri Pelkonen. Pieksämäki: Suosäätiö, lk 367-373.

Piiroinen, Erkki 1991 (1947). Karjalan pyhät kilvoittelijat. Kolmas painos. Joensuu: Ortodoksinen Veljestö.

Rajamo, M. 1944. Suistamon seurakunnan historia. Kuopio.

Razumova, Irina 1996. Pyhä ja maallinen - legenda-aiheet karjalaisessa sadustossa. Näkökulmia karjalaiseen perinteeseen. Toim. Pekka Hakamies. Suomi, vol. 182. Helsinki: Suomalaisen Kirjallisuuden Seura, lk 136-160.

Ronimus, J. V. 1906. Novgorodin vatjalaisen viidenneksen verokirja v. 1500 ja Karjalan silloinen asutus. (Historiallinen Arkisto 20:1.) Joensuu: Joensuun kirjapaino-osakeyhtiön kirjapaino.

Saarikivi, Ritva 1974. Naisen asema ja tehtävät Salmin ortodoksisessa seurakuntaelämässä 19171939. [Laudatur-töö käsikiri. Helsingi Ülikooli teoloogia teaduskonna raamatukogu.]

Sauhke, Niilo 1971. Karjalan praashniekat. Jyväskylä: [Omakustanne].

Sihvo, Hannes 1973. Karjalan kuva. Karelianismin taustaa ja vaiheita autonomian aikana. Diss. (Suomalaisen Kirjallisuuden Seuran Toimituksia 314.) Helsinki: Suomalaisen Kirjallisuuden Seura. Surakka, Aari 1936. Suomen ortodoksisen kirkon historiallisia vaiheita. Sortavala: Suomen kreikkalaiskatolisen kirkon jumalanpalvelus- ja oppikirjain suomennos- ja toimituskunta. Timonen, Senni 1990. Karjalan naisten Maria-eepos. Runo, alue, merkitys. Kirjoituksia vanhan kansanrunon alueellisesta muotoutumisesta. Toim. Pekka Hakamies. (Karjalan tutkimuslaitoksen julkaisuja 92.) Joensuu: Karjalan tutkimuslaitos, 1k 111-148.

Viljanto, Anni 1991. Salmi. Salmin pitäjän muistojulkaisu [2. p.] Jyväskylä: Salmi-säätiö.

Vlassov = Vlasov, V. G. 1990-1991. The Christianization of the Russian peasants. Soviet Anthropology and Archeology, vol. 29 (3), 1k 25-42.

Wartiainen, Eliel 1953. Kun haltiat elivät... Kuvauksia runon ja taian mailta. Raja-Karjalan Säätiön julkaisuja 4. Jyväskylä: [Raja-Karjalan Säätiö].

\section{Kommentaarid}

1. Eliade (1980: 25) järgi on sellisele kristlusele omane elu ja viljakuse austamine ja nende mõlema jätku kindlustamise püüe.

2. Karjala tähendab siin Laadoga-Karjalat, Aunust ja Valge mere lääne- ja lõunarannikut.

3. Rootsis-Soomes neid loomulikult ei koolitatud ega pühitsetud ametisse.

4. Nad olid sõjas toetanud venelasi. 
5. Analoogia ametliku ortodoksse lihavõtte- ja ülestõusmispärimusega - muuhulgas kellade helistamine, hoone ümber käimine - on ilmne.

6. Soome suurvürstkonna ortodokssed kogudused kuulusid kuni aastani 1892 Peterburi metropoliidi alluvusse. Seejärel moodustati neist oma piiskopkond. Soome riik tunnustas seda piiskopkonda iseseisva (autonoomse) kirikuna novembris 1918. Kirikliku õiguse järgi läks piiskopkond Konstantinoopoli patriarhi alluvusse juunis 1923. Juba 1890. aastail koosnes piiskopkonna vaimulikkond Raja-Karjalas suurelt osalt sünnipärastest karjalastest, kellest paljud olid soomemeelsed.

7. Surnupesuvesi oli kombeks kallata väljapoole maja sellesse nurka, kus seespool olid ikoonid. Samasse nurka valati ristimisvesi koduse ristimise korral (Rajamo 1944: 270, 274) ja kodu õnnistamise puhul pühitsetud vesi (Saarikivi 1974: 101). Niimoodi nähti sündi, kodu rajamist ja surma kõiki inimese elutee teatud etappidena.

8. Preestri positsioon tugevnes ilmselt siiski alles 20. sajandi alguses (vt Genetz 1870: 101102).

9. Slaavitama-termin tuleneb kirikuslaavi keele kiitmist tähendavast sõnast.

10. Teine maailmasõda tähendas Karjala ortodokslusele ja karjalastele sedavõrd suurt murrangut - Karjala loovutamist Nõukogude Liidule ja laialipillatuna elamaasumist Soome eri paikadesse -, et sellele järgneva perioodi rahvapärane usuelu on täiesti iseasi.

11. Võib ka arvata, et tegemist oli omamoodi noorte siirderiitusega, «initsiatsiooniga» täiskasvanute ja abielu maailma (vrd Eliade 1980: 11-12).

12. Omapoolset lisa andsid uus vene rahvalaulutraditsioon, pajatukset ja tantsud (vt Genetz 1870: 90-91). Nende mõju rahvapärase ortodoksluse muutumisse ei ole peaaegu uuritud ning selle teema ulatuslikum vaatlemine pole siingi võimalik. 